811.163.41'367

821.163.41.08-31 Михаиловић Д. https://doi.org/10.18485/sj.2017.22.1.18

ТАЊА Ј. ТАНАСКОВИТ *

Универзитет у Крагујевцу

Филолошко-уметнички факултет
Оригинални научни рад

Примљен: 01. 08. 2016.

Прихваћен: 15. 12. 2016.

\title{
ПОРЕДБЕНЕ КОНСТРУКЦИЈЕ КОЈИМА СЕ ОЗНАЧАВАЈУ ФИЗИЧКА СВОЈСТВА ЧОВЕКА У ДЕЛИМА ДРАГОСЛАВА МИХАИЛОВИЋА
}

\begin{abstract}
У раду су са структурно-семантичког и стилистичког аспекта анализиране поредбене конструкције у романима Петријин венаи, Гори Морава и Чизмаши Драгослава Михаиловића. Корпус је ограничен на један сегмент са антропоцентричном референцијалном вредношћу - на асоцијативно поље „физичка својства човека”. Анализирана поређења, која у великом броју примера прелазе у полуидимоатизоване конструкције услед преосмишљавања значења неке од компоненти, у језику писца представљају једну од стилских стратегија у грађењу сказа и верном сликању појмовног света и вредносног система јунака-наратора.
\end{abstract}

Кључне речи: поредбене конструкције, унутрашња форма, идиоматизација, језичка слика света, стилска функција, језик писца.

\section{1. УВОД}

Основна приповедна стратегија у романима Драгослава Михаиловића јесте хомодијагетичко приповедање, засновано на техници сказа, односно симулацији усменог говора у првом лицу. Јунаци Михаиловићеве прозе су у позицијији да сопственим говором осликају себе и свој поглед на свет. Писац

*takica_7@yahoo.com 
је у романима Петријин венаи, Гори Морава и Чизмаши, у којима представља јунаке ћупријског Поморавља, за стилске константе одредио дијалекатске лексичке нивое и стилске поступке креирања дијагезе који одговарају спонтаном усменом говору. У оквире тих стратегија уврстио је сликовите конструкције, међу којима су најбројнија сликовита поређења различитог степена идиоматизације, којима се реферише на човекове духовне и физичке карактеристике. Такве конструкције у функцији су креирања утиска о спонтаном усменом говору, у ком дијалекатски наратор остварује референцијалност језичким јединицама које му се у складу са тренутним асоцијацијама и комуникативном намером у говорном чину наметну као најпогодније за изражавање дате идеје.

Поређење као један од основних начина упознавања света репрезентује динамику односа људи према изванјезичким ентитетима, јер почива на успостављању сличности између два објекта, односно на њиховом зближавању зарад тренутне карактеризације једног од њих. Дијалектички однос према свету доводи до сталних иновација у класи поређења и до настанка нових компаративних фразеологизама. ${ }^{1}$ Значајна заступљеност поредбених конструкција, које често прелазе у полуидиоматизоване спојеве у књижевно-уметничком тексту заснованом на сказу може се образлагати њиховом изразитом експресивношћу. Поред номинативне, односно референцијалне улоге, њима је својствена експресивна значењска компонента, која је последица специфичне преобразбе значења конструкције речи. Идиоматизоване јединице су носиоци не само рационалне процене сегмената стварности већ и емотивне оцене, те имају изражену конотативну значењску компоненту (уп. Телија 1996: 84, Мршевић Радовић 1987: 16). Аутор романа за сликање унутрашњег света својих јунака користи чињеницу да видови семантичке преобразбе, као и тип значењске мотивације откривају специфичан поглед на свет носилаца језика, што је у складу са тезом Ј. Бартмињског према којој су језик, менталитет и култура једног народа у нераскидивој вези (уп. Бартмињски 2011: 46-69). ${ }^{2}$ Засноване на метафоричној слици сегмената стварности, поредбене и полуидиоматизоване конструкције представљају језичке јединице бремените културним значењем ${ }^{3}$, те их Д. Михаиловић употребљава као ефикасно стилско средство у сликању јунака.

${ }^{1}$ УП. и Б. Јанев (2013: 17): „езикът е динамично и гъвкаво явление, а културата на човека се променя непрекъснато в резултат на постоянното развитие на социума, което води до поява на все по-нови и нови сравнения, допълване и перифразиране на вече съществуващите в речниковия фонд".

${ }^{2}$ Н. И. Толстој (1983: 189-190 и 1995: 63-100) фразеологију повезује са етнолингвистиком. О вези фразеологије и националне културе у српском језику в. и Мршевић Радовић (2008). (2015: 15).

${ }^{3}$ О појму културног значења / културне конотације в. Телија (1996: 214-237) и Вуловић 
0.1. Издвајање тематеске групе „физичка својства човека” из асоцијативног поља „човек” поткрепљено је психолошким теоријама личности у којима се она поима као организација особина које се своде на психичке особености личности и својства физичке конституције (Рот 1988: 41-42). Оваква конфигурација асоцијативног поља „човек” кореспондира са категоризацијом Олге В. Коротун (2002a), према којој се у наивној језичкој слици света издваја холистички концепт човека, слика-концепт унутрашњег (духовна својства) и слика-концепт спољашњег човека (физичка својства). ${ }^{4}$

Карактеризација ликова реферисањем на њихова физичка својства поређењима која често прерастају у фразеолошке спојеве изразито је сврховита. Стилска ефективност ове тематске групе поредбених конструкција реализује се у два смера - присутна је и у формирању слике референта и у карактеризацији говорника који поштује одређену вредносну скалу позиционирајући себе у оквир перспективе оцењивача. Олга. В. Коротун (2006: 103), разматрајући концепт људског тела у филозофији, социологији, психологији и религији, истиче како се људска телесност преображава из чисто биолошке у знаковну функцију - тј. постаје преносилац информација о социјалним, културним, професионалним, интелектуалним својствима човека као објекта и субјекта културе. Телесност тако бива знаковност примарног ранга, док у језику добија функцију секундарног означитеља. Спољашњи изглед, према томе, јесте својеврсни показатељ друштвених релација и човековог односа према свету. Он је константни објекат оцењивања посматрача и у том процесу доводи се у везу са унутрашњим, психичким својствима човека (уп. Коротун 2002а). Стални процес евалуације довео је до тога да је лексички систем којим се реферише на спољашњи изглед човека увелико засићен аксиолошком семантиком, која се очитује кроз оцену пожељно/добро - непожељно/лоше - неутрално (уп. Коротун 2002; Драгићевић 2010: 115-123; и о прагматици језичког знака у: Ристић 2004: 20). Када се семиолошка сложеност асоцијативног поља „физичка својства човека" удружи са комплексном природом фразеологизма као језичкога знака, долази се до знаковног система који је богат културним значењем.

${ }^{4}$ У домаћим монографијама које се баве језичком сликом човека (Штасни 2013; Драгићевић 2001; Драгићевић 2010) издвојена су лексичко-семантичка поља окупљена око хиперсема „физичка својства човека” и „духовна/психичка својства човека”.

${ }^{5}$ В русской наивной (языковой) картине мира воплощено это обыденное представление о типичном (национальном, русском) внешнем облике человека (женщины и мужчины). Коллективные представления народа о каком-либо фрагменте действительности отражены прежде всего в устойчивых словосочетаниях, выражениях. Народное представление о красивой внешности мужчины и женщины состоит из нескольких клише: лицо должно быть бело, румяно, брови - черна соболя, глаза - словно звезды, у женщины - осанка лебединая, походка павиная, у мужчины - сила молодецккая, богатырская. (Коротун 2002: 89). 


\section{1. АНАЛИЗА}

Карактеризација човека поредбеним конструкцијама на основу физичког изгледа у делима Драгослава Михаиловића вршена је с обзиром на утисак о целокупном, начелном изгледу и физичком стању човека, и с обзиром на утисак о изгледу делова тела. Овом приликом пажњу посвећујемо само првој групи, односно холистичкој перспективи физичких својстава човека.

У оквиру теорије значења идиома описују се сви типови асоцирања између ознаке и означених фрагмената стврности (Телија 1996: 87), односно унутрашња форма фразеологизама, што ће бити примарни циљ анализе фразеолошких јединица са доменом „човек” и хиперсемом „физичко својство”, реализованих у романима Петријин венаи, Гори Морава и Чизмаши Д. Михаиловића.

Поредбене конструкције које реферишу на целокупан изглед и физичко стање човека могу се поделити у неколико лексичко-семантичких субпоља окупљених око хиперсема: 1. „висина и телесна конституција”, „стас”, „боја тела”, „старосна доб”, „физиолошко својство”, „телесни састав”, „визуелна перцепција” и „гласање”.

Основна класификација грађе биће извршена према најопштијој, категоријалној интегралној семи на придевске, именичке и глаголске конструкције. Мотивација фразеолошког значења тумачиће се са циљем утврђивања стереотипних слика појмова у локалној говорној заједници, која се шире укључује у националну језичку слику света. Анализа кореспондира са теоријом стереотипа и концепцијом когнитивне дефиниције представљеном у Бартмињски (2011), као и кокогнитивнолингвистичком теоријом прототипа (нпр. Тејлор 2005).

Већина разматраних јединица у овом асцијативном пољу спада у ред поредбених конструкција са тематско-рематском структуром. Она се састоје из левог, базног дела поређења (тема) и десног, компаративног дела или еталона (рема). Тематски део (А) припрема рематску компоненту, која се састоји из поредбене речи (Ц) и еталона (Б) (в. Гољак 2009: 211; Вуловић 2015: 186; Јанев 2013: 45-47; Финк 2000: 95; Финк 1998: 200-201). Ове структуре показују различит степен идиоматизације. Некада су то проста поређења у којима рематски део преузима улогу квантификатора-интензификатора тематске лексеме, али не долази до идиоматизације, односно семантичког преобликовања компонената. Такве компаративне конструкције имају нулти степен семантичке транспозиције (в. Гољак 2009; Вуловић 2015: 204), те се са разлогом у литератури јавља и термин сликовита поређења (нпр. Борјан 2013: образните сравнения), којим се избегава сврставање ове класе у фразеологизме. ${ }^{6}$ Међутим, у радовима у

${ }^{6}$ Н. Вуловић (2015: 186) истиче да није свако поређење фразеолошко. Фразеолошким поређењима углавном се приближавају неистородне реалије (нпр. референт може бити човек, а 
којима се релативизују границе фразеологизама постављене у традиционалној лингвистици (в. Финк 2000, Мршевић Радовић 2008: 157-160, Гољак 2009) употребљава се термин поредбени (компаративни) фразеологизми. У многим примерима у нашој грађи проста поређења прерастају у идиоматизоване спојеве. Поређење је идиоматичније што је слика на којој је засновано нејаснија, мање прозирна. Сликовитост је иманентна особина поредбених јединица, без обзира на степен идиоматизованости. ${ }^{7}$ Поред непотпуне идиоматизације, ове јединице карактерише и спорадична премостивост делова, чиме се у комуникативном чину постиже активни евалуативни однос говорника према референту, односно повећана експресивност израза. Због непотпуне идиоматизације и недовољне устаљености у језику ове јединице не бележе речници општег језика, те се са аспекта традиционалне лексикографије и не сматрају јединицама лексичког система.

Са стилистичког становишта, треба напоменути и то да поредбене конструкције у језику Д. Михаиловића, са својом референцијалном, а онда и конотативном вредношћу у контексту, садејствују са референтним једночланим лексичким синонимима остварујући стилистички ефекат семантичке кумулације. Као експоненти језичке метафоричне слике стварности фразеологизми у том кумулативном процесу имају најистакнутију улогу.

\section{1. Конструкције са придевским категоријалним значењем}

1.1.1.1. Интегрално својство „физичка димензија, величина” окупља придевске поредбене фразеолошке јединице велик као мазгов са значењем „веома велик, висок, гломазан”, и кратак ко (неко) трупче са значењем „изразито низак":

Био је јак и тако кратак, ко неко трупче. Груди јаке имао и још као мали стално се с њи нешто прсио ко да се прави важан. (о псу) (ПВ, 124);

Он је пре времена израстао велики као мазгов и имао гвоздене санке што иду као брзи воз $[\ldots](\Gamma \mathrm{M}, 18){ }^{8}$

еталон предмет, животиња и сл. са доминантном сликовитом представом о некој особини), док се нефразеолошким поређењем упоређују истородне реалије којима је заједничка нека реална особина.

${ }^{7}$ Н. Б. Мечковска (према Вуловић 2015: 214) устаљена поређења, чија је одлика експлицитна сликовитост узрокована смисаоном везом узуалног и дословног значења, сматра класом између идиоматских и неидиоматских израза. Она их не сврстава у фразеологизме јер се еталони јављају у својим основним значењима, те не долази до преименовања референта.

${ }^{8}$ У примерима из романа подвучени су анализирани фразеологизми, а италиком су истакнуте језичке јединице које „подупиру” фразеолошку семантику, односно које са фразеологизмима као хомореферентним јединицама учествују у стилистичком процесу семантичке акумулације. 
Поредбени фразеологизам кратак ко (неко) трупче показује ниски степен идиоматичности. Рематска компонента је придев кратак са спецификованим доменом „човек” и значењем „који је мале висине, низак, мали” (у РСАНУ и PCJ значење/домен 1.в). Типичнији домен употребе придева кратак је „предмет” (у РСАНУ и РСЈ под 1.а.), што значи да се придев семантички слаже са еталоном који није истородан са фразеолошким референтом - фразеологизам реферише на човека, а у еталону је лексема са значењем предмета. Придев у теми је стога помереног домена употребе - од еталона који му је својствен ка неистородном референту, функционише са узуалним преносним значењем, и условљава најнижи степен идиоматичности поредбене конструкције. Рематски део садржи лексему трупче, која је реализована у основном значењу. Тематска лексема реализује стереотипну, прототипску сему појма у еталону турпче: „мало по дужини”. Стереотипна значењска компонента рематског појма постаје доминанта која редупликује архисемско својство тематског придева и добија функцију интензификатора „веома”.

Поредбена конструкција велик као мазгов има ниски степен идиоматичности. Придев у теми реализован је у основном значењу „који је обимом, опсегом изнад просечног, крупан, висок, широк”. Тема је активирала стереотипну сему појма „мазгов” у еталону „велик, крупан”, што је компонента са преносним значењем, пошто је изгубљена представа о реалној величини мазгова. Активирана, првобитно потенцијална сема рематске лексеме у овом споју постаје доминантна и редупликује архисемско својство придева у теми, добијајући функцију интензификатора „веома” у поредбеној конструкцији.

Поређење човека на основу критеријума физичких димензија вршено је у једном фразеологизму са животињом, у другом са предметом. Лексеме у рематском делу садрже прототипско обележје изразите величине - мазгов, односно малих димензија - трупче и управо је на том својству базирана метафорична веза између два појма човека и мазгова односно човека и трупчета.

1.1.1.2. Семантичком микропољу са интегралном семом „стас”, односно „обим тела” припадају конструкције кроз иглене уши да га протнеш са значењем „веома танак, витак”, затим доменом диференцирани парцијални синоними танак ко девојка и витак као момчић (само за особе мушког пола) са значењем „веома витак, привлачан”, подгојен ко старији човек „умерено подгојен, подебео” и дебео као лубеница „веома дебео, гојазан”.

Висок, удешен, танак ко девојка, кроз иглене уши да га протнеш. (Ч, 18)

То је био леп дедица с кратким, ушиљеним, жандарским белим брковима, витак

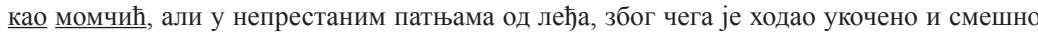
$[\ldots](\Gamma \mathrm{M}, 77)$

[...] а широк стомак му се гура преко њега, видиш, и подгојен ко старији човек, иако није претерано. (Ч, 107-108) 
У чуду га гледам и не одговарам. Дебео је као лубеница и познајем га. Откуд он овде? (ГМ, 157)

Овим се попуњава цео појмовни домен стас са прагматичким ефектима оцене стварности од стране говорника ${ }^{9}$ - од позитивно вреднованих сегмената домена са аспекта пожељности и количине, који развијају семантичку компоненту „привлачан”: веома мршав, витак, преко неутралног, или чак са симпатијама конотираног сегмента: пуначак, до негативне оцене по параметру количине, из перспективе прекомерности: изразито дебео, непривлачан. Фразеологизам кроз иглене уши да га протнеш структурно се разликује од осталих из ове групе. Семантика ове глобалне фразеолошке јединице заснована је на имплицитном поређењу конца и особе по параметру дебљине. Зарад експресивности, избегнуто је успостављање директне метафоричне везе између ова два појма, па је појам „конац”, са којим се пореди људско биће, супституисан изразом за специфичну/стереотипну ситуацију у којој се он налази - конац се протиње кроз иглу. Из специфичне ситуације произилази стереотипна сема „танак” поредбеног појма. Управо ова сема индукује метафоричну везу са потенцијалним својством појма „људско биће”. Конструкција речи која првобитно реферише на прототипску ситуацију појма „конац” пресемантизује се и своди на стереотипну сему овога појма - „танак”, која се даље, померањем домена, транспонује у компоненту са позитивном вредносном оценом „витак, привлачан”. Категоријално придевско значење овог фразеологизма у колизији је са његовом реченичном структуром, за разлику од осталих фразеолошких јединица код којих постоји корелација између структуре и категоријалног фразеолошког значења. У слуачајевима када је корелација нарушена повећана је идиоматичност конструкције. У овом примеру структура се може објаснити елизијом тематске компоненте (довољно) танак да кроз иглене уши можеш да га протнеш.

Рематски делови поредбених конструкција (ко девојка, као момчић, ко старији човек) садрже лексему са значењем особе која је носилац прототипичног својства приписаног тематском делу („танак”, „витак”, „подгојен”, „дебео”), изузев рематски део као лубениия, у ком је компаратум фитоним. Архисемска својства тематских компоненти реализују по једну стереотипну компоненту појмова из реме, док се све остале неутралишу; и то придев танак реализује стереотипну сему „витка” лексеме девојка, придев витак актуелизује стереотипни елемент „витак” појма момчић, лексема подгојен фиксира

${ }_{9}^{9}$ Интерпретирајући Апресјана, С. Ристић (2004: 20-21) прагматику језичког знака дефинише као однос говорника према стварности, садржају исказа и према адресату. Однос према стварности за последицу има општу оцену, оцену по параметру количине и оцену по фактору пожељности/непожељности. Општа оцена се огледа у позитивном, неутралном или негативном ставу према референту, по параметру количине вреднује се референт оценом довољности, недовољности или прекомерности. 
стереотипну сему „пуначак” сложеног номината старији човек, а придев дебео актуелизује стереотипну компоненту „крупна, округла” лексеме лубеница. Сведен на само једну сему, рематски део редупликује архисемско својство појма из теме, у потпуности се десемантизује и почиње да функционише као интензификатор придевског значења. У поређењу подгојен ко старији човек рематски део ко старији човек не врши функцију интензификатора, већ потврђује, конкретизује степен својства исказан придевом у теми, будући да придев подгојен представља умерени ступањ присуства особине на скали прагматичке квантификације. Обележје прагматичке квантификације је неопходност постојања норме у односу на коју се сагледава степен неке особине. Пошто је норма у овом примеру особа чије је стереотипно својство умерена дебљина, онда се рематским делом само потврђује умереност присуства особине у тематском делу фразеологизма. Са аспекта степена семантичког преобразовања поређења витак као момчић и подгојен ко старији човек имају нулти степен идиоматичности, пошто је доминантна стереотипна сема у еталону њено реално својство, а придев у теми реализован је у основном значењу. Компаративна конструкција танак ко девојка показује најнижи степен идиоматичности, а дебео као лубеница нешто виши степен семантичког преобразовања. У првом је тематски придев танак померен од свог основног значења „који је мале дебљине, чији је попречни пресек малог обима” (у РСАНУ значење 1.) у „витак, привлачан” (у РСАНУ значење 2.), док је активирана доминантна сема у еталону нетранспонована. Придев дебео у тематском делу другог поредбеног фразеологизма бива транспонован захваљујући домену примене „човек” и реализује се у значењу „угојен, ухрањен, обрастао масним ткивом" (у РСАНУ значење 2.а. придева дебео). Рематска лексема лубеница у ниском степену у садејству са придевом дебео модификује своју стереотипну сему „округла, попуњена” у „крупна, широка у обиму”. Сведен на доминантну сему рематски део врши улогу значењског интензификатора негативне семантике тематског придева, те читав поредбени фразеологизам развија додатну значењску компоненту „непривлачан”.

Најразгранатије микропоље поредбених конструкција са придевским категоријалним значењем отворило је могућност ступања у синонимски однос између фразеологизама кроз иглене уши да га протнеш, танак ко девојка, који у роману Чизмаши ступају и у однос референтне синонимије, и витак као момчић, који има сужени домен на особе мушког пола. У односу антонимије према наведеном синонимском ланцу стоји фразеологизам дебео као лубеница. Поредбене конструкције танак ко девојка, витак као момчић и подгојен ко старији човек откривају да се прототипско својство витког стаса додељује особама млађег пола, док се својство веће дебљине сматра стереотипним својством старијих мушкараца. 
Мотивисане у свести говорника, ове конструкције уз реализовану референцијалну вредност задржавају асоцијативну везу са почетном, мотивном сликом, што доприноси експресивности и живости описа. У садејству са лексемама у контексту оне, са својим денотативним и конотативним семама, улазе у ланац језичких јединица са ефектом семантичке кумулације. У примеру из романа Чизмаши синонимни фраземи танак ко девојка и кроз иглене уши да га протнеш улазе у однос референтне синонимије (о референтној синононимији в. Ковачевић 2000: 150), редупликујући референцијалне семе, али нудећи две перспективе именовања референта. Поређење витак као момчић у роману Гори Морава улази у однос референтне синонимије са придевом позитивне оцене леп, те заједно ове јединице интензификују општу позитивну семантику, при чему се поредбена конструкција јавља као конкретизатор општијег значења придева леп. Негативно детерминисан соматизам широк стомак и негирана предикативна синтагма претерано подгојен, омогућавају кумулацију семантичких компонената садржаних у поређењу подгојен ко старији човек у роману Чизмаши, при чему се метафорична слика нуди као сликовита надградња већ детерминисаног референта. Делимичне семантичке редупликације у низању хомореферентних јединица у наративу нису комуникативна нужност (уп. Ковачевић 2000: 152-154), већ добијају карактер стилског, експресивног средства у ком најистакнутију улогу има поредбена конструкција, имајући у виду да се сликовите конструкције употребљавају када се прагматички ефекти појава стављају у први план у односу на референцију.

1.1.2. Поредбена конструкција сур ко пиле граорче као семема „изразито пепељаст, сивкаст” припада микропољу „боја тела / коже”, а своје значење остварује поређењем својства човека са животињом:

[...] а лице му изгубило сваку боју, изгледа сур ко пиле граорче [...] (Ч, 205).

Из овог поређења ишчитавамо стереотипну сему појма пиле граорче ${ }^{10}$ - „пепељасто, сивкасто”. Конституент ко пиле граорче, са сложеним номинатом пиле граорче, првобитно је сведен на стереотипну сему „сивкаст” а онда и потпуно десемантизован, са функцијом интензификатора особине исказане лексемом у теми. Сема на коју је сведен еталон није семантички преобразована, али је померена у семској хијерархији у позицију доминанте, што је омогућило низак степен идиоматизације поредбене конструкције. Tertium comparationis реализован је у свом основном значењу. Семантичка компонента која додатно везује значење елемената поредбене конструкције јесте сема негативне вредносне оцене, контекстуално активирана хомореференцијалном клаузом $a$ лице му изгубило сваку боју, и чињеницом о поређењу неистородних појмова,

${ }^{10}$ Уп. РСАНУ: грахорка (дијал. граорка) 3. а. грахораста кокош; кокош ситног перја. 
чиме се својство „сур ко пиле граорче” сматра непрототипском и негативном особином човека.

1.1.3. Младост као сегмент лексичко-семантичког микропоља „старосна доб” сврставамо такође у лексичко-семантичко макропоље „спољашње човекове карактеристике”. Архисему „млад” садржи фразеологизам као роса пролетьа млад са значењем „веома млад”, у примеру:

Да л ће ми мој човек, докторе, који тек двајес девету напунио и у тријесту зашо, који ми је као роса пролетња млад и живота се није нагледао [...] (ПВ, 202).

Тематски придев млад у свом основном значењу „који је у раном добу живота, који није почео да стари" активирао је сродну стереотипну сему лексеме роса „рана, која се дешава рано ујутру, на почетку неког времена” (у РСАНУ значење 1. а. придева рани, и 4.а. придева млад) и транспоновао је у „млада” (у РСАНУ млад 1.а.). Поредбени фразеологизам захваљујући овом преобразовању доминанте семе у еталону садржи средњи степен идиоматизације (рематски део је идиоматизован). Преобразован семантички, еталон преузима функцију значењског интензификатора „изразито, веома”. Рематски део структурно је проширен компонентом која појачава свеукупну експресивност фразема - у питању је атрибут пролетњ $а$ у постпозицији, која је стилистички маркирана. Атрибут пролетњ $а$ такође у својој семској структури има значењску компоненту „млада”, пошто је придев у творбено-семантичкој вези са именицом пролеће, која симболише почетак, односно период младе године. Атрибутски додатак, дакле, и синтаксичком позицијом и семантичком структуром појачава експресивност поредбеног фразема. Стилиској вредности фрезеологизма доприноси и структурна инверзија тематског и рематског дела: рема (као роса пролеть $а)$ ) тема (млад). ${ }^{11}$ У РСАНУ забележен је немаркирана алогична фразеолошка јединица ${ }^{12}$, која почива на оксиморону, са антонимним значењем „стар”: млад као роса у подне. Реализовани фразеологизам као роса пролетъа млад може бити показатељ својеврсне симетрије у језику, испољене кроз тежњу да се на плану лексичких релација успоставе јединице истог творбеног нивоа за именовање супротних појмова.

1.1.4. Двама синонимним фразеологизмима изражава се физиолошко људско својство у великој мери „веома жедна”. У питању су фразеолошке

${ }^{11}$ Необележени, комуникативни редослед компонената је: тема + рема. Више о томе у Јанев (2013: 54-57).

12 У литератури се као творбени / мотивациони модел настанка фразеологизама наводе тзв. алогични фразеологизми (нпр. Јанев [2013: 39-40] примећује тип алогичних сликовитих поређења у којима је укупно значење израза антонимно значењу тематске компоненте, нпр. паметан као амеба, са значењем „глуп”). Д. Мршевић Радовић (1987: 20, 33) приликом разматрања семантичке фразеологизације помиње парадокс, контраст и хиперболу као семантичке транспозиције које се комбинују са метафоричним и метонимијским процесима. 
јединице жедан ко дуга и иелу би реку попила, реализовани као контекстуални синоними у роману Петријин венащ:

- Жедна сам, чини ми ске, ко дуга, целу би реку попила. (ПВ, 16).

Двокомпонентни фразеологизам жедан ко дуга базиран је на стереотипном сегменту значења лексеме $\partial$ zа $^{13}$ да упија течност. Архисема лексеме жедан у тематском делу у каузалној је вези са семом „упија течност” из прототипа појма „дуга” - упија течност јер је жедна. Тај каузалитет омогућио је компоненти дуга аниматну концептуализацију: дуга је биће $\rightarrow$ дуга је жедна (попут бића). У другом кругу семантичке фразеологизације, долази до концептуализације у супротном смеру - човек је дуга (жедан као дуга). У реми се редуплицира компонента „жедан” садржана у теми, те рема преузима функцију интензификатора са значењем „веома”. Носилац средњег степена идиоматизације јесте еталон дуга, који је полуидиоматизован, након што је његова стереотипна сема пресемантизована у смеру персонификације. Тематски део показује нулти степен семантичког преобразовања. Објашњење мотивације које смо у овом случају предузели кореспондира са обрадом општејезичког придевског фразема пијан као дуга, односно глаголског пити као дуга у РСАНУ уз именицу дуга са значењем предмета. Драгана Мршевић Радовић (1987: 95; 2008: 158-159) начин обраде у РСАНУ сматра последицом секундарне мотивације фразема пити као дуга у језику, након што је примарна мотивација заснована на представи атмосферске појаве дуге као митског бића - аждаје која пије воду из река и језера и враћа је у виду кише, ${ }^{14}$ заборављена.

Глобални фразеологизам цеелу би реку попила заснован је на метафоричној слици особе која пије реку. У процесу семантичке фразеологизације компонента река модификована је у значење „велика количина воде”, а онда је по метонимијском, каузалном моделу: онај ко пије много воде је веома жедан, читава конструкција пресемантизована у „веома жедан”. Реченична структура фразеолошке јединице у диспропорцији је са категоријалним придевским значењем фразеологизма, што за последицу има виши степен идиоматизованости.

Фразеологизми из овог микропоља реализовани као референтни синоними у роману остварују ефекат семантичке кумулације и разноврсности перспективизације у карактеризацији човека.

${ }^{13}$ РСАНУ: дуга „савијена даска као саставни део бачве, бурета”.

${ }^{14}$ Објашњење мотивације преко поимања атмосферске појаве кореспондира са фраземима у другим словенским језицима: „чеш. pije jako dúha, слов. pit ako dúha, слов. Vedno pije kakor božja marva, укр. smok vódu pié, буг. като смок (пия, смуча)" (Мршевић Радовић 2008: 158). 


\section{2. Конструкције са именичким категоријалним значењем}

Десигнативно својство „особа слабе телесне грађе” са диференцијалним обележјем „слабашна, болешљива особа” елемент је фразеологизма килави Радован. Овај фразеологизам илуструје творбени тип који настаје уопштавањем конкретне појединачне ситуације на локалном нивоу. ${ }^{15} \mathrm{У}$ српском језику нису ретки фраземи са антропонимом засновани на појединачној ситуацији или некој особини везаној за конкретну особу из локалне заједнице. Такви се фразеологизми уопштавају употребом и губе првобитну мотивацију.

„,...] Баш ми ти знаш, слинчо. Килави Радоване. Стално си болес'ан. [...]“ (ГМ, 14)

У овом примеру мотивна сема у фразеолошком значењу јесте одлика конкретног, јединачног референта - Радована - једне особе из уже локалне заједнице. У тренутку када је конструкција изгубила референцијалну везу са конкретном особом, тј. када је еталон Радован почео значити било коју слабашну, болешљиву особу, процес идиоматизације је окончан. Одсуство тематског елемента у структури фразеологизма, који би катафорски најавио семантички садржај реме (нпр. *болесан ко килави Радован), условио је виши степен идиоматизације. Стереотипна сема се подразумева а не најављује тематском лексемом у свом основном значењу. Изостављањем тематског придева, поређење је скраћено до метафоре, а потенцијално придевска архисема „слаб, болешљив" постала је пратећа, диференцијална компонента именичког категоријалног значења „особа”, чији је носилац управна именица синтагме.

Овај фразеологизам, који карактерише виши степен идиоматизације, није забележен у расположивим речницима општег језика, што значи да је регионално обојен.

\section{3. Конструкције са глаголским категоријалним значењем}

У овој групи дају се уочити микропоља окупљена око хиперсема „боја тела”, „визуелна перцепција” и „гласање”.

1.3.1. Глаголска поредбена конструкција стања (имати) боју на мушмулу са значењем „бити модар” и архисемом „боја тела” реализован је у роману Чизмаши:

Он нешто намрштен, љут. И ситан, спечен, има боју на мушмулу. (Ч, 267).

И лексеме у перифрастичној тематској компоненти и рематска јединица реализоване су у основном значењу; нема преосмишљавања њихових семан-

${ }^{15}$ У Мршевић Радовић (1987: 33) налазимо примере овог творбеног типа са антропонимом, попут: луда Наста (каже се за онога који беспослен лута, без циља), уредио као Наста (каже се кад ко што лоше уради), прошао као Петроније на Брајићима и сл. 
тичких саставница, те конструкција имати боју на мушмулу има нулти степен идиоматизованости. Рематска компонента своди се на доминантну стереотипну сему еталона „модра”, која је инкорпорирана у значење теме. Конституент на мушмулу нема улогу интензификатора тематске компоненте, као што је најчешће случај код поредбених конструкција, већ је њен спецификатор. Стереотипна сема у реми прецизира, конкретизује значење појма у теми, пошто је у тематском појму инкорпорирана, док у конструкцијама са рематским делом у функцији интензификатора појам у рематском делу дословно понавља архисему појма у теми. Поређење има боју на мушмулу у значењској је вези са сур ко пиле граорче, пошто их повезује хиперсема „боја тела”. Обе конструкције имају негативну семантику, те потврђују руменило као пожељно својство боје људске коже, које је показатељ доброг здравља.

1.3.2. Микропоље „визуелна перцепција” чини глаголски поредбени фразем ништа не видети ко кокошка са значењем „слабо видети” у примеру:

Оћорео сам од самице, ништа не видим ко кокошка. (Ч, 274).

Носилац семантичке фразеологизације јесте поредбена конструкција ко кокошка, у којој је тематски глагол видети активирао стереотипну сему у вези са квалитетом вида „слабо види”. Кокошке слабије виде у сумрак и ноћу, па отуда и изрази типа кокошје, ноћно слепило, ${ }^{16}$ кокошја болест, ${ }^{17}$ кокош $(u) j u$ ви ${ }^{18}$, што сведочи о томе да је у наивној језичкој слици света својство слепила активно стереотипно семантичко обележје лексеме кокошка. Стереотипна, доминантна сема еталона кокошка релативизује негирано значење глагола у теми: фразеологизам ништа не видети ко кокошка нема значење „ништа не видети”, које засебно реализује компонента у теми, већ „слабо видети”. Рема са улогом квантификатора-конкретизатора глаголског значења транспонује архисемско значење теме, те овај фразеологизам чини јединицом са средњим степеном идиоматизације. Семантика фразеолошке јединице у сагласности је са природом негације у српском језику, будући да се негирана лева страна фразеологизма слаже значењски са негативном семантиком десне стране. У делима Д. Михаиловића тзв. алогични фразеологизми (*видети ко кокошка) нису продуктиван творбени тип.

1.3.3. Микропоље повезано хиперсемом „гласање” садржи два микрореда окупљена око архисема „говорити” и „невербално се гласати”. У оквиру семантичког поља „говорити” издвајају се поредбене конструкције са диференцијалном семом „гласно” у које убрајамо викати као глуваћ са значењем „веома гласно викати”, цичати као љуте гује „говорити веома високим и одсечним

\footnotetext{
${ }^{16}$ В. РМС под слепило.

${ }^{17}$ В. РСАНУ под болест.

${ }^{18}$ В. РСАНУ под кокош(и)ји.
} 
гласом, сиктати”, драти се ко/кај магарац и драти се кај ован „неумерено се драти, одавати неумерено снажан, продоран глас".

Генерал му брзо одговара; циче они један на другога као љуте гује, просто ти се кожа јежи [...] (Ч, 95);

„А? шта?“, виче Пејовић као глуваћ. „Нисам те чуо! Шта си рек’о?“ (ГМ, 149);

Него, ако се тако нешто догоди, ти се - дери. И то се дери тако да све пуца, дери се ко магарац, док се не усере од стра. (Ч, 43);

Већ у шес ујутру пијаног можеш да га видиш [...] и отуд се из све снаге дере кај ован $[\ldots](\Pi \mathrm{B}, 317)$.

Рематске компоненте ових конструкција функционишу као интензификатори основног глаголског значења у теми. То им омогућава чињеница да се еталони схватају као прототипични вршиоци радњи исказаних глаголским компонентама, те се у процесу семског преструктурирања и семантичког пражњења своде на дату стереотипну сему. Сегмент стереотипа пејоративне атрибутивне именице глуваћ, са значењем „особа слабог слуха, глува особа” јесте гласно говорење, као последица слабог чула слуха. Стереотипно својство гласног оглашавања у говорној заједници приписано је и животињама овну и магарцу, као њихова реална особина,. Поређења са овим еталонима карактерише ниски степен идиоматизације, будући да су заснована на приближавању неистородних појмова и да стереотипна сема рематске лексеме добија позицију доминанте. У случају фразеологизма цичати као љуте гује глаголска компонета својом семантиком истиче не само стереотипну сему појма „гуја” која се односи на квалитет звука (висок) него и ону која се тиче интензитета (јак), а коју не можемо приписати гуји као реално својство. Због тога се овај поредбени фразеологизам истиче вишим степеном идиоматизације у тематској скупини „говорити гласно”. Перцепција гласања змије као цичања у језичкој слици света може се објаснити изменом доживљаја звука, односно перцепцијом висине звука (својствене змији) као јачине, при чему се успоставља семантичка компонента „продорности” у појму „гласање змије”. У народу је познато да змија испушта звук налик шиштању, који није интензиван, али је висок и продоран, што је потврђено забележеним доменом примене глагола ииштати у РМС: 2.6 „испуштати оштар глас, сиктати (о змији)”. Синоним сиктати употребљен у дефиницији у РМС има одређења 1. „испуштати оштар и испрекидан глас који подсећа на продужено изговарање гласа "c" (о змији и неким птицама)". Описана значења глагола гласања својствених домену змија/гуја отварају потенцијал да се перципирање звука шуштања покрене ка домену „цичати”, односно да се висина тона перципира и као појачан интензитет. Такво померање у перцепцији гласања еталона подржано је још и постојањем компоненте непријатности која је садржана у значењу глагола цичати и у стереотипу гласања змије. Уз идиоматизованост доминантне семе у еталону укупној идиоматизацији фразеологизма доприноси и транспозиција глагола у теми од „одавати снажан, продоран глас” ка „снажно и непријатно 
викати". С друге стране, фразеологизам циччати као љуте гује може се тумачити као јединица са дубљим културуолошким значењем, чија је мотивација данас изгубљена. Гуја, односно змија у српској и шире словенској демонолошкој традицији заузима значајно место. Лексема змај је у етимолошкој вези са змија (Скок 1973 : 657), и сматра се њеном метастазом. И змији и змају приписује се атрибут ватре. Змија се сматра симболом ватре (в. Мршевић Радовић 2008: 165-166), а змај описује као велика крилата змија која бљује ватру (Чајкановић (1994: 267). Епифанију змаја В. Чајкановић (1994: 268) описује на следећи начин: „њу прате [...] грмљавина, севање, тутњава, потрес, врло јак ветар, од његове рике тресе се земља". Контаминирана демонолошка својства змије и змаја могу бити објашњење особине интензивног гласања приписаног гуји у анализираном фразему ичиче као љуте гује.

1.3.4. У оквиру микропоља „гласање” функционише фразем са диференцијалном семом „невербално гласање”: ко коґ фрктати са значењем „правити интензиван шум избацивањем ваздуха кроз нос".

Вода готово ледена и ја и дркћем и ко кољ фркћем, а певам и радујем се. (Ч, 283)

Прототипски домен употребе глагола фрктати јесте лексема коњ (в. РСАНУ под фрктати), која је еталон у реализованом поређењу. Тематски глагол се у поређењу стога реализује у узуалном преносном значењу са доменом „човек”. Померање домена са животиње на човека у конструкциоји ко кољ фрктати условљава низак степен идиоматизованости поређења. Поредбеноначинска конструкција ко кољ има функцију спецификатора и интензификатора помереног глаголског значења. Рематском компонентом фразеологизма човеку се приписује прототипска слика животиње. У процесу фразеологизације именица коњ семантички се редукује на своју прототипску сему „фрктати”, те функционише као интензификатор референцијалне вредности глагола са антропоморфним доменом. На првом нивоу фразеологизације, дакле, рематска компонента сликовито враћа глагол на изворни домен, а на другом нивоу интензификује значење глагола са реализованим антропоморфним доменом.

\section{2. ЗАКЉУЧАК}

Поредбене конструкције, у чијој је основи приближавање различитих појмова зарад карактеризације једнох од њих, у језику романа Д. Михаиловића доприносе ефекту усмене реализације наратива, те се могу сматрати стилском стратегијом у оквиру технике сказа. У великом броју примера ове конструкције прелазе у полуидиоматизоване спојеве услед различитог степена преосмишљавања садржаја њихових конституената - од нултог, код поређења у којима су и лексема у теми и лексема у реми реализоване у основном значењу 
(нпр. витак као момчић), преко ниског, код поређења у којима су тематски или рематски део реализовани са узуелним преносним значењем, односно полуидиоматизовани (нпр. кратак као трупче, драти се ко магараи), до средњег степена идиоматизације код поређења у којима је доминантна сема у еталону семантички преобразована тако да не представља реално својство појма (нпр. пити као дуга, као роса пролетьа млад). Категоријална семантика фразеологизма килави Радован (именичка), затим кроз иллене уши да га протнеш (придевска) и иелу би реку попила (придевска), у којима постоји диспропорција између структуре и значења, условљена је испуштањем тематског придевског појма (болестан, танак, жедан), чиме је укинута поредбена структура. Елидирањем тематске лексеме и поредбене свезе стереотипна сема поредбеног појма постала је категоријално-семантичка доминанта. У осталим примерима у којима поредбене конструкције садрже тематску лексему (било да је она придевска или глаголска), која катафорски припрема стереотипну сему у еталону, значењска прозирност је већа, односно метафорична слика је јаснија, а категоријално значење зависи од врсте тематске лексеме, односно није пресудно за тип семантичког преобразовања конструкције.

Без обзира на степен идиоматичности, поређења представљају спецификум језичке слике света, јер је сам одабир еталона показатељ структуре стереотипа појмова једног језичког система. У том смислу се и поредбене конструкције ефективно уклапају у регионално обојени наратив на осталим језичким нивоима у анализираним романима. Сликовитост као иманентно својство свих типова поређења, која се манифестује кроз укрштање референцијалног и конотативног плана, као и њихова прозирна мотивација за говорнике српског језика указују на активни евалуативни однос говорника према референту, односно према сопственим и туђим физичким особинама. То значи да су телесна својства битан показатељ физичког здравља, карактерних особина и естетских мерила говорника. Семантичка анализа показује да су у ексцерпираним романима подједнако заступљена поређења која означавају позитивне и она која означавају непожељне физичке карактеристике, док има и оних која су вредносно неутрална.

Инкорпорирање фразеологизама у текст романа међу остале једночлане лексичке хомофункционалне јединице вршено је зналачки са циљем семантичке кумулације и прецизности у описивању. У процесу успостављања хомореференцијалности и семантичке кумулације фразеологизми са прозирном мотивацијом имају доминантну семантичку улогу јер нуде специфичну двореферентну перспективу именовања - реализујући се истовремено са идиоматизованим значењем и основним значењем својих конституената. 


\section{ИЗВОРИ}

ГМ: Драгослав Михаиловић, Гори Морава, Београд: СКЗ, 1994.

ПВ: Драгослав Михаиловић, Петријин венаи, Београд: Нолит, 1981.

Ч: Драгослав Михаиловић, Чизмаши, Београд: БИГЗ - СКЗ - Просвета, 1984.

\section{ЛИТЕРАТУРА}

Бартмињски 2011: J. Бартмињски, Језик - слика - свет, превела Марта Бјелетић, Београд: SlovoSlavia.

Вуловић 2015: Н. Вуловић, Српска фразеологија и религија, Београд: Институт за српски језик САНУ.

Гољак 2009: С. Голяк, Устаљена поређења у српском и белоруском језику са аспекта идиоматичности, Научни састанак слависта у Вукове дане 38/1, Београд: Филолошки факултет, 211-220.

Драгићевић 2001: Р. Драгићевић, Придеви са значењем људских особина у савременом српском језику, творбена и семантичка анализа. Београд: Институт за српски језик САНУ.

Драгићевић 2010: Р. Драгићевић, Вербалне асоиијаиије кроз српски језик и кулmуру, Београд: Друштво за српски језик и књижевност Србије.

Јанев 2013: Б. Янев, Образните сравнения с антропоцентричен характер в българския и английския език, Пловдив: Университетско издателство „Пасий Хилендарски”.

Ковачевић 2000: М. Ковачевић, Стилистика и граматика стилских фигура, Крагујевац: Кантакузин.

Коротун 2002: О. Владимировна Коротун, Образ-концепт «внешний человек» в русской языковой картине мира, Диссертация на соисканиеученой степени кандидата филологических наук, Омский государственный университет, <http://newstar.rinet.ru/ minlos/thesis/ Korotun2002.pdf >. 28. 3. 2016.

Коротун 2002а: О. Владимировна Коротун, Концептуализация представлений о внешности человека в русской языковой картине мира, Омский государственный университет им. Ф.М. Достоевского, $<$ http://www.rusnauka.com/3_ANRR_2009/Philologia/39990.doc. $\mathrm{htm}>$. 6. 4. 2016. 
Коротун 2006: О. В. Коротун, Представления о теле и телесности человека в гуманитарных науках как экстралингвистический прототип образа-концепта внешний человек, Вестник Омского универсиmema, 2006. № 2. C. 102-106.

Мршевић Радовић 1987: Д. Мршевић-Радовић, Фразеолошке глаголско-именичке синтагме у савременом српскохрватском језику, Београд: Филолошки факултет.

Мршевић Радовић 2008: Д. Мршевић-Радовић, Фразеологија и наџионална култура, Београд: Друштво за српски језик и књижевност Србије.

Ристић 2004: С. Ристић, Експресивна лексика у српском језику, Београд: Институт за српски језик САНУ.

PMC: Речник српскохрватскога књижевног језика, I-VI, Нови Сад: Матица српска (и Матица хрватска I-III), 1967-1976.

Рот 1988: Н. Рот, Психологија личности, 14. издање, Београд: Завод за уџбенике и наставна средства.

PCАНУ: Речник српскохрватског књижевног и народног језика, I-XVIII, Београд: САНУ, 1959-2010.

PCJ: Речник српског језика, Нови Сад: Матица српска 2007.

Скок 1973: P. Skok, Etimologijski rječnik hrvatskoga ili srpskoga jezika, knjiga treća, ponii'-Ž, Zagreb: Jugoslavenska akademija znanosti i umjetnosti.

Тејлор 1995: J. R. Taylor, Linguistic Categorization, Prototypes in Linguistic Theory, Second Edition, Clarendon Press, Oxford. https://www.scribd. com/doc/227747493/John-R-Taylor-Linguistic-CategorizationPrototypes-in-Linguistic-Theory-Oxford-University-Press-USA1995-1-1. 31. 3. 2016.

Телија 1996: Н. В. Телия, Русская фразеология, семантический, прагматический и лингвокультутологический аспекты, Москва: Школа «Языки русской культуры».

Толстој 1983: Н. И. Толстой, О предмете этнолингвистики и ее роли в изучении языка и этноса, редакт. Н. И. Толстой, Ареальные исследования в языкознании и этнографии язык и этнос, Ленинград: Академия наук СССР, Институт этнографии им. Н. Н. Миклухо-Маклая, Институт славяноведения и балканистики ленинградское отделение института языкознания, 181-191.

Толстој 1995: Н. Иљич Толстој, Језик словенске културе, Ниш: Просвета. 
Финк 1998: Ž. Fink, Leksikografska obrada frazema tipa biti dobra srca i čovek dobra srca, u: Filologija, knjiga 30-31, Zagreb: HAZU, 199-207.

Финк 2000: Ž. Fink, Tipovi frazema-fonetksih riječi, Zbornik radova s Međunarodnoga znanstvenog skupa Riječki filološki dani, knjiga III, Rijeka, 93-98.

Чајкановић 1994: В. Чајкановић, Стара српска религија и митологија, приредио Војислав Ђурић, Београд: БИГЗ-Просвета.

Штасни 2013: Гордана Штасни, Речи о човеку, Нови Сад:Филозофски факултет у Новом Саду.

\section{COMPARATIVE STRUCTURES THAT INDICATE PHYSICAL CHARACTERISTICS OF MAN IN NOVELS WRITTEN BY DRAGOSLAV MIHAILOVIC}

\section{Summary}

In this paper we analyze the structural, semantic and stylistic aspect of comparative constructions used in novels Petrijin venac, Gori Morava and Čizmaši by Dragoslav Mihailović. Corps is limited to the thematic field «physical properties of man». Comparative constructions in the language of the writer are one of the stylistic strategy in building techniques of verbal narration and faithful presentation of the conceptual world and the value systems of the hero-narrator.

Key words: comparative constructions, internal form, idiomatization, language world wiev, stilistic function, language of the writer.

Tanja J. Tanasković 